\title{
THE HOUSE THAT IS NOT THERE: THE HOME FEELING IN JONATHAN RABAN'S LANGUAGE IN FOREIGN LAND
}

Francesca Machìi

University of Palermo, Italy

\begin{abstract}
:
This work aims to analyse the novel of the journalist and novelist Jonathan Raban, Foreign Land, trying to highlight how, through the language used, the author manages to elaborate a personal, intimate and even dramatic vision of themes such as the relationship between man and the environment, the sense of uprooting and the love for the sea that are typical themes of travel literature within which this novel is enrolled. More specifically, the text, taken from a work of reading analysis and translation of the Rabanian work from English to Italian, aims to highlight the metaphorical dimension of the home feeling made particularly effective by the parallelism between the inner dimension of the characters and language used by the author.
\end{abstract}

Keywords: English literature; English language; travel; landscape

\section{The literary text: the themes and the author's point of view}

In his first work Foreign land (1984) Jonathan Raban uses the protagonist of the story to provide the reader his personal view of reality. Raban is also a novelist, and his skills as a travel writer, his keen observation, sensitivity to the details of weather and transportation, the ability to draw ideas from autoctones - carry over almost intact into this work. Through it "which clearly sits in the category of novel", as Raban says, both biographical and fictional elements mixed with fantastic creations feed a universe from which the readers cannot escape the background to Foreign Land, the feeling for both land and sea, is one of the strongest aspects of this contemporary English tale. The literary text is "an authentic and indispensable witness" (Lando, 1993: 113) not only to understand the attitude of the man with regard to the environment but in particularly to understand how Raban deals with the topic: travel which in this work is treated metaphorically as a continuous way to redemption. All the themes covered in the novel certainly are drawn from the author's personal travelling experience: the immigration, the passion for the sea, the departure from the native land, England, the journey represent the sense of personal estrangement of the writer of which George Gray, the protagonist of the novel is the alter ego.

i Correspondence: email francesca.machi@unipa.it 
George Grey, the protagonist, a former British naval officer, has run a "bunkering" station on the coast of a former Portuguese colony, now began the (fictitious) Marxist West African state of Montedor. He has lived for some years in Montedor's "easygoing, festive" (F.L.: 45) capital of Bom Porto and has even shared the attentions of Vera, the mistress of Montedor's minister of communications. Life in Montedor has been good, but now George is retiring home, to his native land England.

The choice of the romance genre supports the author's need to share his experience with the readers. Moreover, a rich instance of the enduring legacy of Romantic travel is provided by the innovative work of Jonathan Raban, because, as Jarvis points out, his books give vigorous new life to the exemplary Romantic metaphor of self-discovery (Jarvis, 2010).

The autobiographical element emerges above all from the description of the places as the language is the most representative tool of the writer. "His style", Dancygier says, "is thus an exceptionally clear example of the way in which the construction and manipulation of mental constructs influence the choice of linguistic form, not only within a phrase or sentence, but also in the structure of the narrative"(Dancyngier, 2005: 100).

The novel has a modern language without falling into banality: there are slang and linguistic mixture and also technical register and code switching.

In Foreign Land the biographical element is based on the descriptions, numerous, of the landscapes that give the measure of the amount of places lived or imagined by the author and his relationship with Nature. This strong relationship is particularly evident when he talks about the sea, natural element in which the author shows that he feels comfortable and at the same time it is a metaphor for the strangeness that pervades the novel and its protagonist from the first to the last page. Raban creates a semantic area around the sea. In the novel the sea is the common denominator of all places of life. The sea is the element to which the writer shows himself inextricably linked, as he declares in an interview in which he reveals his great passion for water (Raban, 2006).

\section{The language: linguistic symbolism}

As concern the language, all the themes of the novel seem to be represented by the marinisation process of the language of the characters. This process is certainly not new to English contemporary literature, just think of the illustrious example offered by The Waves by Virginia Wolf. In her novel the Nature marks the stages of the characters' life and The Waves which represent the flux of time are a sort of musical background: it is no surprising that this is the most stylized of her novels! In it, the interludes written in italics, the beginnings of each of the nine sections of the novel, constitute the image of the existence of the characters, reflected by the marine, terrestrial and celestial scenery. From here the title appears in all its symbolic meaning of "The eternal flow of reality advancing from the horizon to reverse and break on the beaches of conscience"(Guiguet, 1965 in Marucci: 156).

Whereas in the Rabanian novel the Nature is inside the life of the characters, it is not only the mirror, but it influences their existence. Whether they are tied to the sea or the mainland, 
their involvement is both physical and cultural and their language is their most immediate expression. No doubt as in Wolf's novel, in Foreign Land the movement and the noise of the sea are the soundtrack to the story. In every scene and in every description, the sea is evoked by language. Here below there is a passage that is an example of how the marine imagery fits forcefully into a scene of the novel and what meaning it takes:

"He watched the tail lights of Diana Pym's mud spattered car weave tough the dark strand of pines and round granite buttress of the headland. As the sound of the engine was lost behind the rock. It was replaced by the slow inquisitive suck and slap of the sea below the cottage and the rattle of dry branches overhead. He found his head suddenly full of words. The girl on the screen was singing...The words tinkled stupidly.

The fitted themselves to the noises of the sea, and gravelly waves turned into a band playing from a long way off. George could hear drums and saxophone in it and the steep descending scale of a solo clarinet" (F. L.: 68).

This interesting piece contains some central themes of the novel. The relationship between man and Nature is lived in a key undoubtedly positive: man while accepting the superiority of Nature itself, draws from it the energy to improve, as contrast, the noise of the car, symbol of human technology is replaced by the sound of the sea. In front of the musicality of Nature the words that crowd in the mind appear stupid, nonetheless they mix with the noise of the sea giving life to a symphony that comes from far away.

Moreover, the sound of nature is even more accentuated by the use of words such as: Slap; suck; rattle; that recall the sound of waves and the rustle of leaves. While the image of the band playing from afar and the musical instruments that George hears, the saxophone, the drum and the clarinet allude to another fundamental theme: that of the stranger, the lonely traveller, symbolized by that descending and melancholic sound of the solo clarinet, which emerges distinctly from the sound of the other instruments that play the symphony.

The linguistic symbolism of the author, however, is not limited to individual and sporadic scenes in the text, but it is constant, from the first to the last chapter. Think of the way Raban describes the sea, the way he transmits to us the strength of this element, his movement, his unpredictability, through strongly evocative terms: "the ripping sea, wrinkled sea, the sea slide, round and under, the sea burbling..." (Foreign Land)

The same liquid consonants " 1 " and " $\mathrm{r}$ ", according to the definition of linguistics scholars (Lyons 1982 ; Simone, 1994), which recur in the words indicated evoke for themselves the aquatic element.

It was previously spoken about the marinisation of language, meaning an extension of the lexicon related to the concept of "sea", to all the elements of the novel. In fact, often places and characters are described through metaphors, similarities and analogies that have to do with the marine semantic universe. This is what happens, for example, when Raban describes a landscape on the mainland. Here the metaphor is used to describe the Sahara Desert "the wind had blown, in into waves and ripples; red ocean of scorched rubbled..."(F.L.: 47), re-proposing once again the 
contrast between the mainland and the sea. Elsewhere, is the sea that recalls the land with words such as: "the sand coloured, the sea came creaming slandtwise up the beach in a south Westerly gale" (F.L.: 257) ; or through the similitude: "the sea was as pale as lime before it spilled over into ragged white moustaches of foam" (F.L.: 278).

As we have already said, the sea represents the narrator's point of view. "The leaves was waving...(F.L.: 11), the room seem to float...(F.L.: 10), the news lay like a splash ...(F.L.: 11), the word stood out on the page like an atoll in an ocean" (F.L.: 278). These definitions are just some of the similarities that link the earthly universe to the aquatic universe.

Even the other characters of the story fit into this idiosyncratic relationship and in turn, they are linked to semantic and lexical micro-areas that define them. Sheila, George's daughter, for example, that represents George's consciousness, is characterized by concept verbs such as think, know, want, feel that denote her brain nature. Also, according to the marine point of view of the author and the protagonist, Sheila is "the vessel of probity" (F.L.: 34).

The semantic universe used by Raban to describe Diana Pym, the elderly singer that George meets in St. Cadix at a party at some friends' house and with which he weaves an intense friendship, brings out another opposition rooted in the natural universe. Diana is rooted to the mainland, as the goddess of hunting, she takes strength from her rooting with the territory. She is "the good gardener" and this link is evident both from her words and from the language used by the author to describe the woman: Car, garden, home, mud, land, to park, to climb, are some of the words that occur in the text and characterize her. Diana is unfamiliar with the sea and with respect to this element her feelings are expressed by terms that show discomfort such as: scary, alarm, landsick. It is clear that maritime space and ground space are compared through these two characters, Diana and George whose behavior and different sensations are influenced by their bond. Sometimes are the dialogues that set a pace for this contrast "It's disorienting being on a boat. It feels as if you might suddenly find the sky right under your feet" (F.L.: 146), says Diana and George replies "I think that's what I like best about it: I like the way it makes one moment seem quite different from another"(F.L.: 152) and then "it's looks so bald when the sea's out, I'm afraid", Diana Pym said. "No, it's charming", (F.L.: 152) George answered. George's statement is important because in pitting the two characters in contrasting each other Raban reiterates the another essential theme of the novel that is the sense of not belonging to any place, even to that of origin, the condition of outsider embodied by the protagonist.

\section{George Gray the outsider}

Yet none of these connotations that distinguish the characters assume a qualitative predominance over the other. Nature, in all its multiple and antithetical aspects, as in the case of the land/sea opposition, is never seen in a negative key. And it's once more through the language that the Rabanian characters seem to express the harmony of the relationship between man and environment. Raban's work is all pervaded by this deep topic of "characters in a landscape" (Raban, 2006), in the sense that the landscape in which a character lives or is formed strongly influenced 
it. "The character is essentially fluid", he affirms, "it alters according to the circumstances in which it finds itself." (Raban, 2006)

However, the analysis of the language used by Raban can only be considered concluded through the most complex character of the novel, the protagonist George Gray, whose point of view as we have already told coincides with that of the author/narrator. In him the process of marinisation is total and represents his progressive and definitive departure from the earth, and his alienation from his loved ones. Think about the terms that often recur in his speeches: "water, blue, sea, ocean, dark sky, cliff, tide, sail, beam, boat".

The sea is the natural element with which George identifies and which reflects all his feelings. Even when his boat Calliope is compared to a train it is evident that his human dimension is moved from land to sea. The same emotional and sentimental universe is expressed, lyrically, throughout the text with metaphors that have to do with the semantic field of water and sea as in the following passage "He swam, to his bride through a sea of beautiful words,"(F.L.: 269). And even his weak link with the mainland is symbolically represented by the repeated images of the boat tied to the mainland only by a rope: "He stood in a snakepit of a wet coir ropes. Hauling, in hand over hand as he freed Calliope of her final attachment to Cornwall" (F.L.: 220).

The same concept is expressed in another passage later: "Now he was ready to go. Calliope was connected to the ground by a single anchor" (F.L.: 330). Images that emphasize not only George's feeble bond but also his impending abandonment of the mainland.

It is evident that the language of the character, that conceptually coincides with that of the author, as the narrative proceeds becomes more and more intimate. In the final part of the novel the dialogues are increasingly rare and give way to descriptions both of the external and interior landscapes. When the protagonist decides to leave to embark on his solitary journey, immersing himself in the marine universe, the language of the novel becomes less discursive, taking the form of an on-board diary, and George himself renounces to communicate with his fellow men because "full of the sea he had lost the words you needed for the shore" (F.L.: 266) and begins to turn into a real sea creature.

The fundamental concept around which Raban builds the personality of his main character is that of the stranger, the lonely traveller, the unsettled man. George tells us: "He had never had a proper place of his own before. He had always been a lodger in other people's house and had picked up the lodger's habit of passing through without leaving tracks" (F.L.: 319). All the places George has been, London, Cornwall, the Middle East, Africa, he borrowed them, in none of them has ever really put its roots. The figure of the uprooted traveller is linked to that of the foreigner. A character who has found various forms in literature of all time, the stranger ended up taking on the aura of an almost mythical figure. Just think of Moses and Ulysses, the first biblical hero, destined to bring the marginalized people to the Promised Land, and the second, the pagan hero, symbol of human wit, "the adventurer, the traveler, the one who has greatly seen and suffered greatly, who becomes a stranger in his wandering in the eyes of those who meet him" (Ceserani, 1987: 7).

That of the stranger, however, before a literary theme can be defined as an existential condition, lived by those who are in a place that is not their own, find themselves facing a social, environmental and cultural reality, different from their own. It is a cultural projection that is part 
of the imagination of all communities. The more compact and identified they are, the more they will refuse the foreigner, sometimes loading it with negative connotations. To George Gray every place is a foreign land as he is a foreigner to every place. He belongs to nowhere and again it is the language that strongly emphasizes the sense of extraneousness. He is identified as the one who comes from another place "he comes from" and his non-belonging to a place is not only obvious but also emphasized by members of the community. George's step in London - among those who he calls Londoners - perfectly expresses these psychological mechanisms. There is a sense of delusion that pervades him every time he comes back to a place, that what happens in London when he gets back to see his daughter Sheila, after many years of absence. Here Raban uses these words to describe the vision of George's native town as it appears now to him: "Letdown; insomniac; dingy; ruins", and the people he meets "are pallid, spotty and fat as they'd spent the last few years doing nothing. They look like nothing more than "utility furniture" (F.L.: 54). Even when he is in St Cadix at his old friends' house, his condition of being an outsider to the small community of residents is proved by Raban use of a language full of references to the semantic field of travel and the strange. And once again the dichotomy mainland /sea is underlined as something that deeply cut away George from the other people. He also uses irony to highlight the evident distance between George and the others. He says "in St. Cadix West Africa was on the wrong side of the park" (F.L.: 52).

Dancygier says that in Raban's stories of sea travel, his perspective defines what is moving and what remains stationary (Dancygier 2005: 112), and in fact the dichotomy mainland/sea is, once more, represented by the words used to describe the mainland.

The protagonist's sense of alienation becomes stronger and stronger as the novel approaches its conclusion. When on the boat with Diana, a woman who he met in St. Cadix and who become friend with, while sailing, George sees the English coast, he turns to the woman and says, "Look - there's your land. Over there" (F.L.: 180). How can we not perceive the emphasis put on the pronoun your, that excludes George's belonging to the mainland? The passages mentioned show once again the thesis put forward so far.

\section{Conclusions}

It has been said that George Gray's condition of extraneousness characterizes this character everywhere he goes. So, he can be assimilated in all his manifestations to the mythical Ulysses for the contradictory impulse that, on the one hand, pushes him to leave and, on the other, to return to his place of origin. According to the terminology used by Porteus (1985), it is evident that George can be placed in the category of who he calls the away-insider, one who finds his own realization in the journey by sea. And like a new Ulysses he will hear the song of the sirens, embodied by his boat whose strongly evocative name is Calliope. The last powerful final scene of the novel ideally reestablishes that sense of emotional stillness and security that George can only find at sea: the further away he is from the land the more he finds his home. 
Raban here describes, slowly, solemnly, George's moving away from his native Britain. The power of nature rises again from the language, the similitudes and the metaphors that he uses to give emphasis to what is happening:

"He slipped past the last of the fleet. The sea was as wide and open as the sky, far bluer than the constrained and muddy British seas. It was the colour of brocade ribbed with silver threads....They were over the Continental Shelf now, with the ground plunging away from under the boat. There were a thousand meters of water below, then two thousand, three thousand, four thousand. The sea was deeper than mountains were high" (F.L.: 351).

Later, the boat is compared to a living creature:

"Soaring clear of the falling ground Calliope was flying...sustained by her diaphanous skin of blue water,..." (F.L.: 351).

And finally, the last description is for George's feeling while is abandoning the mainland. Here, Raban summarizes the themes of the story by bringing them back to a balanced dimension:

"sat, arms spreadegled on the starboard side settee, and felt the waves of his heart pumping blood in foxtrot time. The sea chuckled at his back, the abyss opened under the keel, but for now... George was home" (F.L.: 356).

As emerges several times from the text, Jonathan Raban's novel Foreign land, written in the first phase of his writing career, puts at the back the fundamental themes of the rabanian poetics, the sea, the travel, the sense of uprooting, the relationship between man and nature; themes that will be taken up later in all his most mature works. The choice of the literary genre, however - in which fictional elements are mixed with the real and autobiographical elements of the author gives the work an intimate and dramatic dimension that makes immediate the reader's empathy towards themes typical of the travel literature rendered here through the vivid, precise language and narrative, contemporary and deeply human. It has been said that there is a parallelism between the mental dimension of the characters and the language used by the author; for this reason it was chosen to give this work the title of The House That Is Not There: The home feeling, which is not only an allusion to the boat Calliope where the protagonist will decide to dwell but because it represents, above all, the mental dimension of George Gray who rejects the idea of a home dimension of life, as well as the idea of home itself, synonymous with putting down roots and, therefore, being forced to stop. Nonetheless George Grey, can be seen a contemporary everyman searching simultaneously for home and self.

The home feeling will then be that particular feeling that will give shape to the circular and eternal journey of the protagonist, perpetually far from the house that does not belong to him and in constant tension towards those real/surreal roots that aims to strengthen. In short, George Gray becomes an emblem of the contradictory and dialectical link between man and nature. 
Moreover, Raban, thanks to the peculiarities of his language, is a modern writer, who with his own sensitivity and personal experience, has given an important contribution to the treatment of the theme of the "stranger". The enigmatic title of the work, Foreign land, therefore takes on the character of a challenge launched by Raban to those who, taking inspiration from the novel, can wonder about the meaning of "foreign land" and that sense of bewilderment that each individual, in modern Western civilization, often cultivates in the deepest part of himself.

\section{Conflict of Interest Statement}

The author declares no conflicts of interests.

\section{About the Author}

Dr. Francesca Machì currently holds the position of English Language Teacher at the Academic Language Centre and at the Department of Humanistic Sciences of the University of Palermo. She is also an English teacher at the secondary school $1^{\text {st }}$ grade. Her research interests refer to language studies in literature and language studies connected to theory \& practice of language teaching with a particular focus on Flipped Teaching in the EFL classes, CLIL Methodology and Ludic methodology in the English classes and EFL teacher training.

\section{References}

\section{a. Journal articles}

Porteous, J. (1985). Literature and Humanist Geography. Area, 17(2), 117-122., from http://www.jstor.org/stable/20002164, Retrieved May 30, 2021.

\section{b. Articles by DOI}

Berberich, Christine (2010). "Writing England, Finding the Self: Jonathan Raban and the Travelogue as Identity Tool". In Process. Leiden, The Netherlands: Brill. https://doi.org/10.1163/9789042030763 017

Dancygier Barbara (2005). "Blending and narrative viewpoint: Jonathan Raban's travels through mental spaces". https://doi.org/10.1177\%2F0963947005051281

Jarvis Robin (2005). "Self-discovery from Byron to Raban: The Long Afterlife of Romantic Travel, Studies in Travel Writing" https://doi.org/10.1080/13645145.2005.9634974

\section{c. Online documents}

Battersby E, 1999 Journeys to the edge of the world https://www.irishtimes.com/news/journeysto-the-edge-of-the-world-1.262794, Last Access 2 May 2021

Dickinson A. 2010 Jonathan Raban: 'I felt pretty happy that I was still alive' https://www.theguardian.com/books/2016/dec/30/jonathan-raban-author-recoverystroke-fears-dis-united-states, Last Access 31 May 2021 
Digs D, 2012 The Englishman on the Hill https://www.cityartsmagazine.com/issues-eastside2009-04-englishman-hill/, Last Access 31 may 2021

Edwards Thomas R. 1986 Not quite home is the sailor The New York Times Book Review November 3, 1985, Section 7, Page 9 https://www.nytimes.com/1985/11/03/books/notquite-home-is-the-sailor.html, Last Access 24 April 2021

"Foreign Land" Literary Masterpieces, Volume 10 Ed. Frank Northen Magill. eNotes.com, Inc. 1986 eNotes.com https://www.enotes.com/topics/foreign-land\#in-depth-foreign-land-1, Last Access 14 Jun 2021

Weich D. 2006 Jonathan Raban an interview. https://www.powells.com/post/interviews/jonathan-raban, Last Access 26 May 2021

\section{d. Books}

Adams, Percy J., 1962 Travellers and Travel Liars, 1660-1800, Berkeley and Los Angeles: California University Press.

Adam, Percy J, 1983 Travel literature and the evolution of the novel The University Press of Kentucky, Lexington.

Bonadei R, 2007, I sensi del Viaggio, FrancoAngeli, Roma.

Ceserani R, 1998 Lo straniero Laterza, Roma-Bari

Fasano, 2006, Letteratura e Viaggio, Laterza, Roma-Bari

Lando, F. 1993, Fatto e Finzione, Etaslibri, Milano

Lyons J., 1982, Lezioni di Linguistica (Italian translation ) Laterza, Roma-Bari

Hornby, A.S., 2020 Oxford Advanced Learner's Dictionary of Current English, Oxford University Press, 10 ed.

Porteous D., J., Literature and Humanistic geography , in Area, Vol. 17, pp. 117-122

Raban, J, 1985 Foreign Land, Picador, London

Raban, J, 1986 Coasting London, Collins \& Harvill.

Raban, J, 1988, For Love \& Money: Writing and Reading a Travelling 1968â®1987 Picador, London

Simone, R, 2005, Fondamenti di Linguistica 15 ed. Laterza, Roma-Bari

Wolf, V., 2000, The Waves, Wordsworth Edition, Ware 
Francesca Machì

THE HOUSE THAT IS NOT THERE: THE HOME FEELING

IN JONATHAN RABAN'S LANGUAGE IN FOREIGN LAND

Creative Commons licensing terms

Author(s) will retain the copyright of their published articles agreeing that a Creative Commons Attribution 4.0 International License (CC BY 4.0) terms will be applied to their work. Under the terms of this license, no permission is required from the author(s) or publisher for members of the community to copy, distribute, transmit or adapt the article content, providing a proper, prominent and unambiguous attribution to the authors in a manner that makes clear that the materials are being reused under permission of a Creative Commons License. Views, opinions and conclusions expressed in this research article are views, opinions and conclusions of the author(s). and European Journal of Literature, Language and Linguistics Studies shall not be responsible or answerable for any loss, damage or liability caused in relation to/arising out of conflicts of interest, copyright violations and inappropriate or inaccurate use of any kind content related or integrated into the research work. All the published works are meeting the Open Access Publishing requirements and can be freely accessed, shared, modified, distributed and used in educational, commercial and non-commercial purposes under a Creative Commons Attribution 4.0 International License (CC BY 4.0).

European Journal of Literature, Language and Linguistics Studies - Volume 5 | Issue 2 | 2021 